\begin{tabular}{|c|c|}
\hline \multirow{3}{*}{ 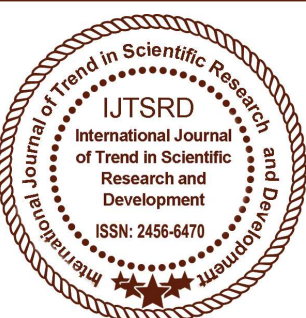 } & $\begin{array}{l}\text { International Journal of Trend in Scientific } \\
\text { Research and Development (IJTSRD) }\end{array}$ \\
\hline & International Open Access Journal \\
\hline & ISSN No: 2456 - 6470 | www.ijtsrd.com | Volume - 2 | Issue -3 \\
\hline
\end{tabular}

\title{
Women Entrepreneurship in Ranchi - Problems and Prospects
}

\author{
Dr.Ritushree Narayan \\ Assistant Professor, Computer \& Information \\ Science, Usha Martin University, \\ Ranchi, Jharkhand, India
}

\author{
Dr. Valeria Lakra \\ Dy. Director (Information) \\ Birsa Agriculture University, \\ Ranchi, Jharkhand, India
}

\section{ABSTRACT}

The educated Indian women have to go a long way to achieve equal rights and position because traditions are deep rooted in Indian society where the sociological set up has been a male dominated one. Despite all the social hurdles, Indian women stand tall from the rest of the crowd and are applauded for their achievements in their respective field. The transformation of social fabric of the Indian society, in terms of increased educational status of women and varied aspirations for better living, necessitated a change in the life style of Indian women. She has competed with man and successfully stood up with him in every walk of life and business is no exception for this. These women leaders are assertive, persuasive and willing to take risks. They managed to survive and succeed in this cut throat competition with their hard work, diligence and perseverance. The present paper endeavors to study the concept of women entrepreneur-Reasons women become entrepreneurs -Reasons for slow progress of women entrepreneurs in India - suggestions for the growth of women entrepreneurs-Schemes for promotion \& development of women entrepreneurship in IndiaCase study of a women entrepreneur of Ranchi.

Keywords: Entrepreneurship, Women, Business, Gender

\section{INTRODUCTION}

The educated women do not want to limit their lives in the four walls of the house. They demand equal respect from their partners. However, Indian women have to go a long way to achieve equal rights and position because traditions are deep rooted in Indian society where the sociological set up has been a male dominated one. Women are considered as weaker sex and always made to depend on men folk in their family and outside, throughout their life. The Indian culture made them only subordinates and executors of the decisions made by other male members, in the basic family structure. While at least half the brainpower on earth belongs to women, women remain perhaps the world's most underutilized resource. Despite all the social hurdles, India is brimming with the success stories of women. They stand tall from the rest of the crowd and are applauded for their achievements in their respective field. The transformation of social fabric of the Indian society, in terms of increased educational status of women and varied aspirations for better living, necessitated a change in the life style of Indian women. She has competed with man and successfully stood up with him in every walk of life and business is no exception for this. These women leaders are assertive, persuasive and willing to take risks. They managed to survive and succeed in this cut throat competition with their hard work, diligence and perseverance. Ability to learn quickly from her abilities, her persuasiveness, open style of problem solving, willingness to take risks and chances, ability to motivate people, knowing how to win and lose gracefully are the strengths of the Indian women entrepreneurs.

\section{CONCEPT OF WOMEN ENTREPRENEURS}

Women Entrepreneurs may be defined as the women or a group of women who initiate, organize and 
operate a business enterprise. The Government of India has defined women entrepreneurs as -an enterprise owned and controlled by women having a minimum financial interest of 51 per cent of the capital and giving at least 51 per cent of the employment generated in the enterprise to womenl. Women entrepreneurs engaged in business due to push and pull factors which encourage women to have an independent occupation and stands on their on legs. A sense towards independent decision-making on their life and career is the motivational factor behind this urge. Saddled with household chores and domestic responsibilities women want to get independence. Under the influence of these factors the women entrepreneurs choose a profession as a challenge and as an urge to do something new. Such a situation is described as pull factors. While in push factors women engaged in business activities due to family compulsion and the responsibility is thrust upon them.

\section{OBJECTIVES AND RESEARCH METHODOLOGY OF THE STUDY}

The study is based on secondary data which is collected from the published reports of RBI, NABARD, Census Surveys, SSI Reports, newspapers, journals, websites, etc. The study was planned with the following objectives: To evaluate the factors responsible for encouraging women to become entrepreneurs To study the impact of assistance by the government on women's entrepreneurship. To study the policies, programmes, institutional networks and the involvement of support agencies in promoting women's entrepreneurship. To critically examine the problems faced by women entrepreneurs.

\section{REASONS FOR WOMEN BECOMING ENTREPRENEURS}

The glass ceilings are shattered and women are found indulged in every line of business. The entry of women into business in India is traced out as an extension of their kitchen activities, mainly $3 \mathrm{P}^{\prime} \mathrm{s}$, Pickle, Powder and Pappad. But with the spread of education and passage of time women started shifting

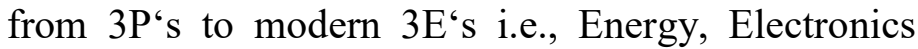
and Engineering. Skill, knowledge and adaptability in business are the main reasons for women to emerge into business ventures. Women Entrepreneur's is a person who accepts challenging role to meet her personal needs and become economically independent. A strong desire to do something positive is an inbuilt quality of entrepreneurial women, who is capable of contributing values in both family and social life. With the advent of media, women are aware of their own traits, rights and also the work situations. The challenges and opportunities provided to the women of digital era are growing rapidly that the job seekers are turning into job creators. Many women start a business due to some traumatic event, such as divorce, discrimination due to pregnancy or the corporate glass ceiling, the health of a family member, or economic reasons such as a layoff. But a new talent pool of women entrepreneurs is forming today, as more women opt to leave corporate world to chart their own destinies. They are flourishing as designers, interior decorators, exporters, publishers, garment manufacturers and still exploring new avenues of economic participation. The following flow chart shows the reasons for women becoming entrepreneurs Innovative thinking New challenges and opportunities for self fulfillment Employment generation Freedom to take own decision and be independent Government policies and procedures Family occupation Need for additional income Bright future of their wards Success stories of friends and relatives Role model to others support of family members Education and qualification self identity and social status

\section{REASONS FOR SLOW PROGRESS OF WOMEN ENTREPRENEURS IN RANCHI}

The problems and constraints experienced by women entrepreneurs have resulted in restricting the expansion of women entrepreneurship. The major barriers encountered by women entrepreneurs are:

$>$ The greatest deterrent to women entrepreneurs is that they are women. A kind of patriarchal- male dominant social order is the building block to them in their way towards business success. Male members think it a big risk financing the ventures run by women.

$>$ Male chauvinism is still prevalent in many parts of the country yet. Women are looked upon as -abla i.e. weak in all respects. In a male dominated society, women are not treated equal to men that act as a barrier to woman's entry into business.

$>$ Women entrepreneurs have to face a stiff competition with the men entrepreneurs who easily involve in the promotion and development area and carry out easy marketing of their products with both the organized sector and their male counterparts. Such a competition ultimately results in the liquidation of women entrepreneurs. 
$>$ Lack of self-confidence, will-power, strong mental outlook and optimistic attitude amongst women creates a fear from committing mistakes while doing their piece of work. The family members and the society are reluctant to stand beside their entrepreneurial growth.

$>$ Women in India lead a protected life. They are even less educated, economically not stable nor self-dependent which reduce their ability to bear risks and uncertainties involved in a business unit.

$>$ The old and outdated social outlook to stop women from entering in the field of entrepreneurship is one of the reasons for their failure. They are under a social pressure which restrains them to prosper and achieve success in the field of entrepreneurship.

> Unlike men, women mobility in India is highly limited due to many reasons. A single women asking for room is still looked with suspicion. Cumbersome exercise involved in starting with an enterprise coupled with officials humiliating attitude towards women compels them to give up their spirit of surviving in enterprise altogether.

$>$ Women's family obligations also bar them from becoming successful entrepreneurs in both developed and developing nations. The financial institutions discourage women entrepreneurs on the belief that they can at any time leave their business and become housewives again.

$>$ Indian women give more emphasis to family ties and relationships. Married women have to make a fine balance between business and family. The business success also depends on the support the family members extended to women in the business process and management.

$>$ Women's family and personal obligations are sometimes a great barrier for succeeding in business career. Only few women are able to manage both home and business efficiently, devoting enough time to perform all their responsibilities in priority.

$>$ The educational level and family background of husbands also influences women participation in the field of enterprise.

$>$ Absence of proper support, cooperation and backup for women by their own family members and the outside world people force them to drop the idea of excelling in the enterprise field. They are always making many pessimistic feelings to be aroused in their minds and making them feel that family and not business is a place meant for them.
$>$ Many women take the training by attending the Entrepreneurial Development programme without an entrepreneurial bent of mind. Women who are imparted training by various institutes must be verified on account of aptitude through the tests, interviews, etc.

$>$ High production cost of some business operations adversely affects the development of women entrepreneurs. The installations of new machineries during expansion of the productive capacity and like similar factors discourage the women entrepreneurs from venturing into new areas.

Women controlled business are often small and it is not always easy for women to access the information they need regarding technology, training, innovative schemes, concessions, alternative markets, etc. Just a small percentage of women entrepreneurs avail the assistance of technology and they too remain confined to word processing software in the computer. They hardly make use of advanced software available like statistical software SAP, Accounting Package like TALLY, Animation software 3D MAX, internet, etc.

Lack of awareness about the financial assistance in the form of incentives, loans, schemes etc. by the institutions in the financial sector. So the sincere efforts taken towards women entrepreneurs may not reach the entrepreneurs in rural and backward areas.

Achievement motivation of the women folk found less compared to male members. The low level of education and confidence leads to low level achievement and advancement motivation among women folk to engage in business operations and running a business concern. Apart from the above discussed problems there may occur other series of serious problems faced by women entrepreneurs as improper infrastructural facilities, high cost of production, attitude of people of society towards the women modern business outlook, low needs of enterprise. Women also tend to start business about ten years later than men, on average. Motherhood, lack of management experience, and traditional socialization has all been cited as reasons for delayed entry into entrepreneurial careers.

\section{SUGGESTIONS FOR THE GROWTH OF WOMEN ENTREPRENEURS}

Right efforts from all areas are required in the development of women entrepreneurs and their 
greater participation in the entrepreneurial activities. Entrepreneurship basically implies being in control of one's life and activities and women entrepreneurs need to be given confidence, independence, and mobility to come out of their paradoxes. The following measures are suggested to empower the women to seize various opportunities and face challenges in business.

- There should be a continuous attempt to inspire, encourage, motivate and cooperate women entrepreneurs.

- An Awareness programme should be conducted on a mass scale with the intention of creating awareness among women about the various areas to conduct business.

- Attempts should be there to enhance the standards of education of women in general as well making effective provisions for their training, practical experience and personality development programmes, to improvise their over-all personality standards.

- Organize training programmes to develop professional competencies in managerial, leadership, marketing, financial, production process, profit planning, maintaining books of accounts and other skills. This will encourage women to undertake business.

- Vocational training to be extended to women community that enables them to understand the production process and production management.

- Skill development to be done in women's polytechnics and industrial training institutes: Skills are put to work in training-cum-production workshops.

- Educational institutes should tie up with various government and non-government agencies to assist in entrepreneurship development mainly to plan business projects.

- International, National, Local trade fairs, Industrial exhibitions, seminars and conferences should be organized to help women to facilitate interaction with other women entrepreneurs.

- Women in business should be offered soft loans \& subsides for encouraging them into industrial activities. The financial institutions should provide more working capital assistance both for small scale venture and large scale ventures.

- Making provision of micro credit system and enterprise credit system to the women entrepreneurs at local level.

- The weaker section could raise funds through various schemes and incentives provided by the government to develop entrepreneurs in the state. E.g. the Prime ministers Rozgar Yojana, The Khadi and Rural village industries scheme, etc.

- In the initial stages women entrepreneurs may face problems but they must persevere, believe in themselves and not give up mid way.

- Attempts by various NGO's and government organizations to spread information about policies, plans and strategies on the development of women in the field of industry, trade and commerce. Women entrepreneurs should utilize the various schemes provided by the Government.

- Women should try to upgrade themselves in the changing times by adapting the latest technology benefits. Women must be educated and trained constantly to acquire the skills and knowledge in all the functional areas of business management. This can facilitate women to excel in decision making process and develop a good business network

- Self help groups of women entrepreneurs to mobilize resources and pooling capital funds, in order to help the women in the field of industry, trade and commerce can also play a positive role to solve this problem.

- Women's entrepreneurship must be examined both at the individual level (i.e. the choice of becoming self-employed) and at the firm level (the performance of women owned and managed firms) in order to fully understand the differences between men's and women's entrepreneurship.

To establish all India forums to discuss the problems, grievances, issues, and filing complaints against constraints or shortcomings towards the economic progress path of women entrepreneurs and giving suitable decisions in the favor of women entrepreneurs and taking strict stand against the policies or strategies that obstruct the path of economic development of such group of women entrepreneurs. Thus by adopting the following aforesaid measures in letter and spirit the problems associated with women can be solved. Entrepreneurship is not a bed of roses to women. Women participation

- in many kinds of economic activities to complement to their family income, their participation in no way reduces their family duties. The task of women has become more tedious and full of challenges. Let us all make efforts to help women rediscover her.

\section{RECOMMENDATIONS}


International Journal of Trend in Scientific Research and Development (IJTSRD) ISSN: 2456-6470

The elimination of obstacles for women entrepreneurship requires a major change in traditional attitudes and mindsets of people in society rather than being limited to only creation of opportunities for women. Hence, it is imperative to design programmes that will address to attitudinal changes, training, supportive services. The basic requirement in development of women entrepreneurship is to make aware the women regarding her existence, her unique identity and her contribution towards the economic growth and development of country. The basic instinct of entrepreneurship should be tried to be reaped into the minds of the women from their childhood. This could be achieved by carefully designing the curriculum that will impart the basic knowledge along with its practical implication regarding management (financial, legal etc.) of an enterprise. Here are some suggestions to increase the role of women entrepreneurs:-

- Infrastructure - Infrastructure set up plays a vital role for any enterprise. Government can set some priorities for women entrepreneurs for allocation of industrial plots, sheds and other amenities. However, precautionary measures should be undertaken to avoid the misuse of such facility by the men in the name of the women.

- Personality Development- Attempts should be there to enhance the standards of education of women in general as well making effective provisions for their training, practical experience and personality development programmes, to improvise their over-all personality standards.

- Self help groups of women entrepreneurs- Self help groups of women entrepreneurs can mobilize resources and pool capital funds to help the women in the field of industry, trade and commerce.

- Business Development Training Programs - It includes basic day-to-day management training like how to keep track of accounts, handle taxes and understand compliance rules and regulations. They can also focus on strategy and the longrange success of a business from writing a business plan to targeting specific markets, along with product innovation within business clusters and incubators.

- Access to Finance Programs- Efforts to facilitate access to finance for women entrepreneurs typically encompass initiatives that reform restrictive bank and regulatory policies. Such reforms accept less traditional forms of collateral, look at a lender's willingness to repay and simplify business registry. They also help financial institutions develop innovative loan and savings products for female entrepreneurs.

- To establish all India forums to discuss the problems, grievances, issues, and filing complaints against constraints or shortcomings towards the economic progress path of women entrepreneurs and giving suitable decisions .

\section{REFERENCES}

1. BhardwajG.N. et al, (2012), "Women Entrepreneurship in India: Opportunities and Challenges" $\mathrm{CH}$ Institute of management and communication, vol2http://www.chimc.in/Volume2.1/Volume2Iss uel/GurendraNathBhardwaj. Pdf

2. Global Entrepreneurship Monitor (2012) GEM 2011 Global Report. Published online, http://www.gemconsortium.org

3. Rao, K., (2004), Women Entrepreneur in Lower Middle Class Families and their Problems, Research Paper Presented at National seminar on Women Entrepreneurship - A Need for Training and Curriculum Development held by Development of Home Science Extension and Communication, Faculty of Home Science, M. S. University, Vadodara.

4. Saidapur, S et.al, 'Women candle entrepreneurs in Gulbarga district - A micro analysis', Spectrum: A Journal of Multidisciplinary Research', vol.4, 2012, pp. 7-17.

5. Starcher, D. C, 'Women entrepreneurs: Catalysts for transformation',1996, Retrieved July 6, 2001: http:// www.ebbf.org/woman.htm

6. http://web.worldbank.org/WBSITE/EXTERNAL/ TOPICS/EXTGENDER/0,,c ontentMDK:23392727 pagePK:210058 piPK:21 0062 theSitePK:336868,00. html

7. Vishwanathan, R, 'Opportunities and challenges for women in business', 2001 Retrieved July15, 2009 from www.indiatogether.org/women/business/renuka.ht $\mathrm{ml}$

8. http://en.wikipedia.org/wiki/Hina_Shah

9. http://lighthouseinsights.in/tupperware-indiafeatures-hina-shah-director-oficecd-in-the-newshe-can-you-can.html

10. http://www.indiainfoline.com/Research/LeaderSp eak/Hina-Shah-FounderICECD/26947305 